\title{
Enteric Opportunistic Parasitic Infections Among HIV- Seropositive Patients in Kathmandu, Nepal
}

\author{
Sherchan JB, ${ }^{1}$ Ohara $H,{ }^{2}$ Sakurada $S,{ }^{2}$ Basnet $A,{ }^{3}$ Tandukar $S,{ }^{3}$ Sherchand JB, ${ }^{3}$ Bam \\ $\mathrm{D} \mathrm{S}^{4}$
}

${ }^{1}$ Kathmandu University School of Medical Sciences, Dhulikhel, Nepal

${ }^{2}$ National Center for Global Health and Medicine, Tokyo, Japan

${ }^{3}$ Tribhuvan University Teaching Hospital, Public Health Research Laboratory, Kathmandu, Nepal

${ }^{4}$ Dirgh-Jeevan Health Care Research Center, Tripureswar, Kathmandu, Nepal

\section{Corresponding Author}

Jatan B. Sherchan

Department of Microbiology

Kathmandu University School of Medical Sciences

Dhulikhel, Nepal

Email: jatansherchan@gmail.com

\section{Citation}

Sherchan JB, Ohara H, Sakurada S, Basnet A3, Tandukar S, Sherchand JB, et al. Enteric Opportunistic Parasitic Infections Among HIV-seropositive Patients in Kathmandu, Nepal. Kathmandu Univ Med J 2012;38(2):14-17.

\begin{abstract}
Background

Enteric opportunistic parasitic infections are the major source of diarrheal disease in developing countries mainly in Human Immunodeficiency virus (HIV) infected patients.
\end{abstract}

\section{Objective}

The study was to detect enteric parasites causing diarrhea and their association with immune status in HIV-seropositive patients.

\section{Methods}

The present study was conducted in Dirgh-Jeevan Health Care Research Center and Tribhuvan University Teaching Hospital, Public Health Research Laboratory, Kathmandu, Nepal between June 2010 and May 2011 involving 146 Human Immunodeficiency virus (HIV) positive patients. Serostatus from these patients were detected by Enzyme Linked Immunosorbent assay. CD4+ T cell counts were done by flow cytometry. Stool was examined for enteric parasites by microscopy with special staining methods.

\section{Results}

A total of 146 HIV sero-positive patients with and without diarrhea age between 20 to 45 years were included in the study. Of the 146 patients, the protozoan parasitic infection was found in $30.13 \%$ (44/146). Out of 146 patients, 78 had diarrhea in which parasitic infection was $39(50 \%)$ and $7.35 \%(5 / 68)$ protozoal parasites positive cases did not have diarrhea. A significant difference $(p<0.05)$ was observed in the level of infection of intestinal protozoan between the HIV seropositive with diarrhea and HIV-seropositive without diarrhea. Out of 43 patients whose CD4+ T cells were $<200 / \mu l, 29(67.4 \%)$ had opportunistic parasitic infection whereas out of 103 patients whose CD4+ T cells were $\geq 200 / \mu$ l, only 15 (14.56\%) had opportunistic parasitic infection $(P<0.05)$.

\section{Conclusion}

Enteric opportunistic parasitic infections were detected in $30.1 \%$ among HIVseropositive patients and low CD4+ T count indicated high enteric opportunistic infection. Early detection of enteric parasitic infections will help in the management and to improve the quality of life for HIV-infected individuals.

\section{KEYWORDS}

Diarrhea, HIV, Opportunistic parasites

\section{INTRODUCTION}

Enteric opportunistic parasitic infections are major source of diarrheal disease in developing countries mainly in HIV infected patients. The progressive decline and ultimate destruction of immune system functions, which are characteristic for AIDS, usually result in morbidity and ultimately death due to opportunistic bacterial, viral, fungi and parasitic infections. ${ }^{1}$ Gastrointestinal infections are very common in patients with HIV infection or AIDS. ${ }^{2}$ Diarrhea is a common clinical presentation of these infections. Reports indicate that diarrhea occurs in 30-60\% of AIDS patients in developed countries and in about 90 per cent of AIDS patients in developing countries. ${ }^{3}$ The presence of 
opportunistic parasites Cryptosporidium parvum, Isospora belli and Microsporidia are documented in patients with AIDS. $^{4,5}$ Moreover, newly emerging coccidian parasites Cyclospora cayetanensis has been reported from HIV-AIDs patients with severe diarrhea in Nepal, India, Peru, Latin America, United States and Papuwa ne Guinea. ${ }^{6-9}$ Non opportunistic parasites such as Entamoeba histolytica, Giardia lamblia, Trichuris trichiura, Ascaris lumbricoides, Strongyloides stercoralis and Ancylostoma duodenale are frequently encountered in developing countries but are not currently considered opportunistic in AIDS patients. ${ }^{10,11}$ In immunocompromised patients, the intestinal opportunistic parasites probably play a major role in causing chronic diarrhea accompanied by weight loss. ${ }^{12}$ The incidence and prevalence of infection with a particular enteric parasite in HIV/AIDS patients is likely to depend upon the endemicity of that particular parasite in the community. ${ }^{10} \mathrm{C}$. parvum, I. belli and $E$. histolytica has been reported as the most frequently identified organisms in HIV infected individuals with diarrhea from India and other parts of the world. 9,13-15 HIV/ AIDS infection are rapidly causing a major threat in Nepal. But the study on enteric parasite in HIV/AIDS patients in Nepal is very scarce. ${ }^{6}$ Hence the current study was conducted to determine the prevalence of enteric opportunistic parasitic infections among HIV-seropositive patients with and without diarrhea in Kathmandu, Nepal.

\section{METHODS}

The study was carried out in Dirgh-Jeevan Health Care Research Center, Tripureswar and Tribhuvan University Teaching Hospital, Public Health Research Laboratory, Kathmandu, Nepal between June 2010 and May 2011. Ethical approval was taken from IRB prior to study. A total of 146 HIV seropositive patients with and without diarrhea participated in the study after giving consent and provided two consecutive stool samples. Before collecting the samples, patient information such as name, age, sex, occupation, clinical history as well as history of diarrhea, antibiotic and antiparasitic treatment history was obtained. Patients already on antiparasitic and antibiotic treatment were excluded from the study.

Blood samples were collected in plain and ethylenediaminetetraacetic acid (EDTA) vials with five $\mathrm{ml}$ each from all enrolled patients. Serum samples were used for HIV testing. HIV serostatus of the patients was determined by using commercially available ELISA antibody tests (Genetic system, Biorad Labs, USA and Tridot, J Mitra \& Co., India). EDTA blood samples were used for CD4 cell counts and measured by using flow cytometry (Partec, $\mathrm{GmbH}$, Germany). Briefly, $20 \mu \mathrm{l}$ of CD4 PE antibody was placed in to a Partec test tube and $20 \mu \mathrm{l}$ of well-mixed whole EDTA blood was added, mixed gently and incubated in the dark for 15 minutes at room temperature. The mixture was agitated during incubation every five minutes. Eight hundred microliters of CD4 buffer was added to the mixture of antibody and sample and mixed gently. This was then plugged to the counter for counting.

Stool samples were collected in clean wide mouthed, leak proof plastic containers from each patient. Stool specimens were examined microscopically for ova, cysts, oocyst, or parasites, using normal saline and iodine mounts on greasefree slides. Following this, each fresh stool samples were preserved in $10 \%$ formal saline. The preserved samples were concentrated using formal-ether concentration methods and examined for, Oocyst of Cryptosporidium spp, Isospora belli, and Cyclsopora cayetanensis were identified using modified Ziehl-Neelsen staining technique earlier described. ${ }^{9,16,17}$ The data were analyzed using Chi square (x2) test and appropriate statistical software packages.

\section{RESULTS}

The 146 HIV sero-positive patients with and without diarrhea included in the study were aged between 20 to 45 years. Of the 146 patients, the protozoan parasitic infection was found $30.13 \%$ (44/146). Of these 146 patients, 78 had diarrhea in which parasitic infection was 39 (50\%) as shown in table 1 . There was $7.35 \%$ (5/68) protozoal parasites positive of cases without diarrhea. A significant difference $(p<0.05)$ was observed in the level of infection of intestinal protozoans between the HIV seropositive with diarrhea and HIV-seropositive without diarrhea. Although Giardia lamblia and Entamoeba histolytica are not considered as opportunistic pathogen it was included in the study because of increased prevalence of these parasites in developing countries.

Table 1.Distribution of parasitic infection among HIV seropositive patients.

\begin{tabular}{|c|c|c|c|c|}
\hline $\begin{array}{l}\text { Parasitic } \\
\text { species }\end{array}$ & $\begin{array}{l}\text { Cases with } \\
\text { acute diar- } \\
\text { rhea } n=33 \\
(22.6 \%)\end{array}$ & $\begin{array}{l}\text { Cases with } \\
\text { chronic di- } \\
\text { arrhea } n= \\
45(30.8 \%)\end{array}$ & $\begin{array}{l}\text { Cases } \\
\text { without } \\
\text { diarrhea } n= \\
68(46.6 \%)\end{array}$ & $\begin{array}{l}\text { Total no. } \\
\text { of cases } n= \\
146\end{array}$ \\
\hline \multicolumn{5}{|c|}{ Protozoal parasites: } \\
\hline $\begin{array}{l}\text { Giardia } \\
\text { lamblia }\end{array}$ & 10 & 3 & 1 & 14 \\
\hline $\begin{array}{l}\text { Blastocystis } \\
\text { hominis }\end{array}$ & 2 & 4 & 3 & 9 \\
\hline $\begin{array}{l}\text { Entamoeba } \\
\text { histolytica }\end{array}$ & 2 & 5 & 1 & 8 \\
\hline $\begin{array}{l}\text { Cyclospora } \\
\text { cayetanensis }\end{array}$ & 1 & 5 & 0 & 6 \\
\hline $\begin{array}{l}\text { Cryptosporid- } \\
\text { ium parvum }\end{array}$ & 2 & 2 & 0 & 4 \\
\hline Isospora belli & 1 & 2 & 0 & 3 \\
\hline Total & 18 & 21 & 5 & $44(30.13 \%)$ \\
\hline
\end{tabular}

\section{Opportunistic parasites and CD4 count}

In the study, out of 43 patients whose CD4+ T cells were $<200 / \mu$ l, $29(67.4 \%)$ had opportunistic parasitic infection whereas out of 103 patients whose CD4+ T cells were $\geq 200$ / 
$\mu \mathrm{l}$, only 15 (14.56\%) had opportunistic parasitic infection as depicted in table 2.

Table 2.Opportunistic parasitic infections and CD4+ T count among HIV sero-positive patients.

\begin{tabular}{|c|c|c|}
\hline Characteristics & No. Of tested & No. of infection (\%) \\
\hline \multirow{2}{*}{$\begin{array}{l}\text { Gender (HIV pa- } \\
\text { tients): }\end{array}$} & Male: 61 & $26(42.6)$ \\
\hline & Female: 85 & $18(21.2)$ \\
\hline \multirow{2}{*}{$\begin{array}{l}\text { Clinical symptoms of } \\
\text { HIV patients: }\end{array}$} & Diarrhea: 78 & $39(50.00)$ \\
\hline & Non-diarrhea: 68 & $5(7.35)$ \\
\hline \multirow{2}{*}{$\begin{array}{l}\text { CD4 Count (cells/ } \mu \mathrm{l}) \\
\text { of HIV sero-positive } \\
\text { patients }\end{array}$} & $<200: 43$ & $29(67.44)$ \\
\hline & > 200: 103 & $15(14.56)$ \\
\hline
\end{tabular}

\section{DISCUSSION}

Enteric parasitic infections still remains an important cause of morbidity and mortality in developing countries especially among HIV-infected persons with and without diarrhea. ${ }^{18}$ The World Health Organization 2006 defines diarrhea wasting syndrome along with HIV-seropositive patients, the etiology of such diarrhea could either be parasites, bacteria, fungal, enteric virus or HIV itself. ${ }^{12,19}$

In the present study the enteric parasites were detected in $30.13 \%$ from the samples with diarrhea and without diarrhea. There was significant difference the infection of opportunistic parasites among HIV- seropositive cases with diarrhea 50\% (39/78) and without diarrhea 7.35\% (5/68).

There are number of studies reported from Indian and other countries with the high prevalence of intestinal parasites 25 to $50 \%$ which are near to our findings..$^{20-22}$ In the study 43 HIV seropositive patients had CD4 count less than 200 cell/ $\mu$ l with gastroenteritis parasitic infections and the infection of opportunistic parasites was $67.4 \%$ (29/43). Among there parasitic infections Giardia lamblia (32\%) was predominant pathogens followed by Blastocystis hominis, Entamoeba histolytica (18\%), Cyclospora cayetanensis (14\%), Cryptosporidium spp. (9\%) and Isospora belli (7\%). Several studies from India and other parts of the world have reported the difference. ${ }^{23-25}$ The prevalence of opportunistic parasite in patients with CD4 count less than or equal to $200 \mathrm{cell} / \mu \mathrm{l}$ was found in $14.5 \%$. Cellular immunity is the major defense against intestinal parasitic infections, it is therefore, the reduction in CD4 count by the HIV predispose HIV infected patients to opportunistic intestinal persons to opportunistic infections. ${ }^{14,26}$ In our study, CD4 count $<200$ cells/ $\mu$ l found a significantly higher prevalence of protozoan parasitic infections $(p<0.05)$.

C. parvum is a major opportunistic parasitic infection found in other studies. ${ }^{4,27}$ But our study showed low prevalence (9.1\%). Similarly C. cayetanensis $(13.6 \%)$ and I. belli $(7 \%)$ were found in the study correlatives with the study done in India. ${ }^{27}$ Occurrence of cryptosporidium in both diarrhea and non-diarrhea cases indicates high risk of infection of this parasites in Nepal.

Detection rate of Cyclospora in this study was found to be $13.6 \%$ in HIV seropositive patients which does not correlates with the study in India (0.6\%) and similar to other study (11\%). ${ }^{27,} 28$ Isospora belli was found $(7 \%)$ to be predominant cause of morbidity in symptomatic acute and chronic diarrhea. There finding are parallel to those documented in similar studies conducted is different part of world in HIV infected patients. ${ }^{27,28,29}$ Isospora belli infections are commonly seen in chronic diarrhoeal patients with HIV-AIDS in developing countries ranges 12$20 \%$, Entamoeba histolyitca was detected $18 \%$ in our study predominant cases with diarrhea should not neglected otherwise. ${ }^{7,11,22,23,25}$ Difference in the incidence of intestinal protozoal parasitic infection reported by many researchers can be attributed to the difference in geographical distribution of parasites, sanitary practices, level of education, economic status, social behavior and different selection cases. ${ }^{14,24,29-31}$ Although mixed infection is seen in HIV-AIDS patients but in our study we did not observed any such findings. The reason for the same could not ascertain. This could be attributed to the limited study sample and specified place of the country. Moreover, study report on opportunistic parasitic infection among HIV seropositive patients and load of CD4 count in Nepal are very scarce and there is no representative baseline information in the country. ${ }^{32}$ Hence, it is important to investigate further to determine the rate of infection with enteric opportunistic parasites to determine the rate of infection with enteric opportunistic parasite in HIV-AIDS patients in other regions of Nepal which will provide the level of endemicity of the country. Skilled manpower and laboratory support required to investigate the carrier, latent and clinical infection. Stool sample examination with modified acid fast staining method as a concentration might help to investigate the existence of opportunistic parasitic infection in Nepal.

\section{CONCLUSION}

The study indicated that enteric parasitic infection caused diarrhea (31.13\%) of the HIV-seropositive patients. The majority of the infections in the patients with CD4 count $<200$ cells/ $\mu$ l were due to enteric opportunistic parasitic infections. The current finding also highlights the importance of early detection of opportunistic parasitic infections among HIV-seropositive patients. This may help to improve the management and quality of life of HIVinfected individuals. Enteric parasites in order to avoid morbidity and mortality due to opportunistic pathogens.

\section{ACKNOWLEDGEMENT}

This study was supported by National Center for Global Health and Medicine, Tokyo, Japan \& partial logistic support from by Dirgh-Jeevan Health Care and Research Center, Nepal 


\section{REFERENCES}

1. Durack DI. Opportunistic infections and Kaposis sarcoma in homosexual men. New Engl J Med. 1981; 305: 1465-1467.

2. Satheesh KS, Ana than S, Lakshmi P. Intestinal parasitic infections in HIV-infected patients with diarrhea in Chennai. Indian J Med Microbiol 2002; 20 (2): 88-91.

3. Mannheimer SB, Soave R. Protozoal infections in patients with AIDS. Cryptosporidiasis, Cyclosporiasis and Microsporiasis. Infect Dis Clin North Am 1994; 8: 483-498.

4. Mukhopadya A, Ramakrishna BS, Gagandeep K. Enteric pathogens in southern Indian HIV infected patients with and without diarrhea. Indian J Med Res 1999; 109: 80-89.

5. Cegieslki JP, Ortegay R, Kees MC. Cryptosporidium, Enterocytozoon and Cyclospora infection to pediatric and adult patients with diarrhea in Tanzania. Clin Infect Dis 1994; 24: 214-221.

6. Sapkota DA, Ghimere PA, Manandhar S. Enteric parasitosis in patients with HIV infection and AIDS in Nepal. J Nep Health Res Council 2004; 2: $1-5$.

7. Scharschmidt and Fieldman: Protozoal infections in patients with AIDS. Cryptosporidiosis, isosporiasis, cyclosporiasis, and microsporidiosis. Infect Dis Clin North Am 1999; 8: 483-98.

8. Ortega YR, Arrowood M. Cyclospora and Isospora. In Murray PR(ED) Manual of Clinical Microbiology. 8th ed. 2003: p2008-2016.

9. Wurtz RM, Kokcka FE, Peters CS. Clinical characteristics of seven cases of diarrhea associated with a novel acidfast organsism in stool. J Infec Dis 1993; 16: 136-138.

10. Janoff EN, Smith PD. Prospectives on gastrointestinal infections in AIDS. Gastroenterol Clin North Am 1988; 17: 451-463.

11. Ramakrishnan K, Shenbagarathai R, Uma A, Kavitha K, Rajemdran R, Thirumalai P. Prevalence of intestinal parasite infestation in HIV/AIDS patients with diarrhea in Madurai South India. Jpn J Infect Dis 2007; 60: 209-10.

12. WHO case definitions of HIV for surveillance and revised clinical staging and immunological classification of HIV-related disease in adults aged 15 years or older. SEARO Publications on HIV/AIDS: 2006 Available from http://www.searo.who.int.

13. Gumbo Tawanda, Sarbah Steedman, Gangaidzo Innocent T, Ortega Ynes, Streling, Charles R, Carville Angela, et al. Intestinal parasites in patients with diarrhea and human immunodeficiency virus infection in Zimbabwe. AIDS 1999; 13: 819-21.

14. Mohandas K, Sehgal R, Sud A, Malla N. Prevalence of intestinal parasitic pathogens in HIV-seropositive individuals in Northern India. Jpn J Infect Dis 2002; 55: 83-4.

15. Kulkarni SV, Kairon R, Sane SS, Padmawar PS, Kale VA, Thakar MR et. al. Opportunistic parasitic infections in HIV/ AIDS patients presenting with diarrhea by the level of immunosuppression. Indian J Med Res 2009; 130: 63-66.

16. World Health Organization. Basic laboratory methods in Medical Parasitology. Geneva: World Health Organization; 1991:9-31.

17. Sherchand JB, Cross JH. Emerging pathogen Cyclospora cayetanensis infection in Nepal. Southeast Asian J Trop Med Public Health 2001; 32: $143-150$.
18. WHO. Intestinal protozoan and helminthic infections. WHO Technical Report Series 666 Geneva: WHO; 1981.

19. Guerrant R L, Hughes J M, Lima N L, Crane J. Diarrhea in developed and developing countries: magnitude, special settings, and etiologies. Rev Infect Dis 1990; 12: S41-S50.

20. Prasad KN, Nag VL, Dhole TN, Ayyagari A. Identification of enteric pathogens in HIV-positive patients with diarrhea in northern India. $J$ Health Popul Nutr 2000; 18: 23-26.

21. Brink AK, Mahe C, Watera C, Lugada E, Gillks C, Whitworth J. Diarhhoea, CD4 counts and enteric infections in a community-based cohort of HIV-infected adults in Uganda. J Infect Dis 2000; 45: 99-106.

22. Gomez MA, Atzori C, Ludovisi A, Rossi P, Seaglia M, Pozio E. Opportunistic and non-opportunistic parasitic in HIV positive and negative patients with diarrhea in Tanzania. Trop Med Parasitiol 1995; 46: 109-114.

23. Dwivedi KK, Prasad G, Saini S, Mahajan S, Lal S, Baveja UK. Enteric opportunistic parasites among HIV-infected individuals: associated risk factors and immune status. Jpn J Infect Dis 2007; 60: 76-81.

24. Attilli SV, Gulati AK, Singh VP, Varma DV, Rai M, Sundar S. Diarrhoea, CD4 counts and enteric infections in a hospital-based cohort of HIVinfected patients around Varanasi, India. BMC Infect Dis 2006; 6: 3944.

25. Wiwanitkit V. Intestinal parasitic infections in Thai HIV infected patients with different immunity status. BMC Gastroenterol 2001; 1: 3-5.

26. Lee JK, Song HJ, Yu JR. Prevalence of diarrhea caused by Cryptosporidium parvum in non-HIV patients in Jeollanam-do, Korea. Korean J Parasitol 2005; 43: 111-114.

27. Kumar SS, Ananthan S, Laxmi P. Intestinal parasitic infection in HIV patients with diarrhea in Chennai. Indian J Med Microbial 2002; 20 : 88-91.

28. Call SA, Heudebert G, Saag M, Wilcox CM. The changing etiology of chronic diarrhea in HIV patients, with CD4 less than 200/mm3. Am J Gastroenterology 2000; 95: 3142-46.

29. Goodgame RW. Understanding intestinal spore forming protozoa: Cryptosporidia, Microsporidia, Isospora and Cyclospora. Ann Intern Med 1996; 124: 429-41.

30. Chhin S, Harwell J, Bell JD, Rozycki G, Ellman T, Barnett JM. Etiology of chronic diarrhea in antiretroviral-naïve patients with HIV infection admitted to Norodom-Sihanouk Hospital, Phnom Penh, Cambodia, Clinical infectious diseases 2006; 43: 925-932.

31. Weber R, Bryan RT, Owen RL, Wilcox CM, Gorelkin L, Visvesvara GS Improved light microsporidial detection of Microsporidia spores in stool and duodenal aspirate.The Enteric Opportunistic Infections Working Group. N Engl J Med 1992; 326: 161-166.

32. Basnet A, Sherchand JB, Rijal B, Sharma S, Khadga P. Detection of coccidian Parasites and their clinical manifestation, treatment and prophylaxis in HIV infected patients in Tribhuvan university Teaching Hospital. J Scientific World 2010; 8: 51-55. 